\title{
PENGARUH TINGKAT PENGETAHUAN PHBS DENGAN PERILAKU GERMAS MAHASISWA POLTEKKES KEMENKES PALANGKA RAYA
}

\author{
Tri Widodo ${ }^{1}$, Cipto Susilo \\ ${ }^{1}$ Staf pengajar, Program Studi Pendidikan Dokter Universitas Palangka Raya \\ ${ }^{2}$ Staf pengajar Universitas Muhammadiyah Jember
}

\begin{abstract}
ABSTRAK
Latar Belakang. Perilaku Hidup Bersih dan Sehat baik secara nasional sebesar 32,3\% berdasar RISKESDAS 2013, dan Propinsi Kalimantan Tengah masih di bawah rata-rata tersebut. Perilaku Hidup Bersih dan Sehat (PHBS) di sekolah merupakan upaya untuk menggerakan dan memberdayakan seluruh civitas akademik untuk berperilaku hidup bersih dan sehat. HL Bloem (1908) mengidentifikasi bahwa derajat kesehatan masyarakat dipengaruhi oleh 4 faktor yakni: Perilaku, Lingkungan, Pelayanan kesehatan dan Keturunan. Faktor Perilaku dan Lingkungan berperan $75 \%$ lebih pada derajat kesehatan masyarakat. Perbaikan lingkungan dan perubahan perilaku yang lebih baik perlu dilakukan sistematis dan terencana oleh semua komponen bangsa, untuk itu GERMAS menjadi pilihan dalam mewujudkan derajat kesehatan masyarakat lebih baik.

Tujuan Penelitian. mengetahui Pengaruh Tingkat Pengetahuan PHBS dengan Perilaku Germas Mahasiswa Poltekkes Kemenkes Palangka Raya.

Metode Penelitian. Penelitian menggunakan rancangan cross sectional dengan lokasi di Kampus Politeknik Kesehatan Kemenkes Palangka Raya . Populasi dalam penelitian ini adalah seluruh mahasiswa Poltekkes Kemenkes Palangka Raya. Data pengetahuan PHBS dan perilaku germas diambil dengan kuesioner. Data dianalisa dengan Uji Mann Whitney.

Hasil : Berdasarkan data yang diperoleh dalam penelitian ini nilai p sebesar 0,003. Hal ini menunjukkan bahwa ada pengaruh tingkat pengetahuan PHBS dengan perilaku Germas.
\end{abstract}

Kata kunci : PHBS, perilaku Germas, mahasiswa. 


\title{
The Influence of PHBS Knowledge Level with Germas Behavior of Health Polytechnic Students Health Ministry in Palangka Raya
}

\author{
Tri Widodo ${ }^{1}$, Cipto Susilo ${ }^{2}$ \\ ${ }^{1}$ Lecturer Faculty of Medicine, University of Palangkaraya \\ ${ }^{2}$ Lecturer Publich Health University Muhammadiyah of Jember
}

\begin{abstract}
Background. Clean and healthy life behavior both nationally is 32.3\% based on the 2013 RISKESDAS, and Central Kalimantan Province is still below the average. PHBS in schools is an effort to mobilize and empower the entire academic community to behave cleanly and healthy. $H L$ Bloem (1908) identified the degree of public health was influenced by 4 factors : Behavior, Environment, Health Services and Heredity. Behavioral and Environmental Factors contribute 75\% more. Improvement the environment and better behavior change needs to do systematically and planned by all components, and GERMAS becomes the choice in realizing.

Obejctive. know the effect of PHBS Knowledge Level on Germas Behavior of Poltekkes Kemenkes Students of the Palangkaraya.

Methods. The study used cross sectional design with a location on the Poltekkes Kemenkes of Palangkaraya. The population in this study were all students of the Poltekkes Kemenkes Palangka Raya. Data PHBS knowledge and germas behavior were taken by questionnaire. Data analize with Mann Whitney test.

Results: Based on data obtained in this study the was performed with a p value of 0.003. This shows that there is an influence of PHBS knowledge level with Germas behavior.
\end{abstract}

Keywords: PHBS, Germas behavior, students. 


\section{PENDAHULUAN}

Perilaku Hidup Bersih dan Sehat (PHBS) merupakan semua perilaku kesehatan yang dilakukan atas kesadaran sehingga anggota keluarga atau keluarga dapat menolong dirinya sendiri di bidang kesehatan dan berperan aktif dalam kegiatan-kegiatan kesehatan di masyarakat merupakan wujud keberdayaan masyarakat yang sadar, mau dan mampu mempraktekkan PHBS. ${ }^{1}$

Pengetahuan adalah hasil tahu dan ini terjadi setelah orang melakukan penginderaan terhadap suatu objek tertentu. Penginderaan terjadi melalui panca indra manusia yakni: indra penglihatan, pendengaran, penciuman, rasa, dan raba. Pengetahuan atau kognitif merupakan domain yang sangat penting untuk terbentuknya tindakan seseorang (overt behaviour). ${ }^{2}$

Perilaku hidup bersih dan sehat (PHBS) dilakukan melalui 5 tatanan pendekatan yaitu: PHBS di rumah tangga, PHBS di sekolah, PHBS di tempat kerja, PHBS di institusi kesehatan dan PHBS di tempat umum1. Indikator PHBS di sekolah yang ditetapkan pada tahun 2011 oleh Pusat Promosi Kesehatan Kementerian Kesehatan mencakup 8 indikator yang meliputi :

1. Mencuci tangan dengan air yang mengalir dan menggunakan sabun

2. Mengkonsumsi jajanan sehat di kantin sekolah

3. Menggunakan jamban yang bersih dan sehat

4. Olahraga yang teratur dan terukur
5. Memberantas jentik nyamuk

6. Tidak merokok di sekolah

7. Menimbang berat badan dan mengukur tinggi badan setiap 6 bulan

8. Membuang sampah pada tempatnya

Data Riset Kesehatan Dasar 2013 (RISKESDAS) proporsi rumah tangga yang melakukan PHBS berdasarkan indikator yang ada yaitu persalinan ditolong oleh tenaga kesehatan (87,6\%), sumber air bersih baik $(82,2 \%)$, BAB di jamban (81,9\%), tidak merokok di dalam rumah $(78,8 \%)$, perilaku cegah jentik $(77,4 \%)$, menimbang balita $(68 \%)$, aktivitas fisik setiap hari $(52,8 \%)$, cuci tangan dengan benar (47,2\%), memberi ASI ekslusif (38\%) dan konsumsi sayur dan buah setiap hari (10,7\%). Perilaku Hidup Bersih dan Sehat baik secara nasional sebesar $32,3 \%$ berdasar data RISKESDAS 2013, dan Propinsi Kalimantan Tengah masih berada di bawah rata-rata PHBS baik nasional. $^{3}$

Henrik L. Blum (1983) telah mengidentifikasi bahwa derajat kesehatan masyarakat dipengaruhi oleh 4 faktor yakni: Perilaku, Lingkungan, Pelayanan kesehatan dan Keturunan. ${ }^{4}$ Faktor Perilaku dan Faktor Lingkungan memegang peran lebih dari $75 \%$ dari kondisi derajat kesehatan masyarakat. Perbaikan lingkungan dan perubahan perilaku kearah yang lebih sehat perlu dilakukan secara sistematis dan terencana oleh semua komponen bangsa,untuk itu GERAKAN MASYARAKAT HIDUP SEHAT (GERMAS) menjadi sebuah pilihan dalam mewujudkan derajat kesehatan masyarakat yang lebih baik. Mahasiswa 
Politeknik Kesehatan Kemenkes Palangka Raya merupakan calon tenaga kesehatan yang diharapkan menjadi teladan bagi masyarakat dalam berperilaku hidup sehat.

\section{METODE PENELITIAN}

Penelitian ini menggunakan metode penelitian analitik observasional dengan pendekatan cross sectional, yang bertujuan untuk mengetahui pengaruh tingkat pengetahuan perilaku hidup bersih dan sehat (PHBS) terhadap perilaku Germas mahasiswa Poltekkes Kemenkes Palangka Raya.

Populasi pada penelitian ini adalah Seluruh Mahasiswa Poltekkes Kemenkes Palangka Raya.

Sampel diambil berdasarkan teknik random sampling. Besar sampel sebanyak 106 orang.

\section{HASIL PENELITIAN PEMBAHASAN}

DAN

Jumlah total responden sebanyak 106 responden yang terdiri dari 14 responden mahasiswa kebidanan, 34 responden mahasiswa keperawatan dan 58 responden mahasiswa gizi. Tempat tinggal responden yang paling mendominasi adalah tinggal bersama orang tua dan kos masing-masing sebesar $40 \%$ sisanya tinggal bersama family $15 \%$ dan lainnya sebesar 5\%. Kepemilikan jaminan kesehatan mahasiswa yang memiliki ada sebesar 98 (78\%) responden dan yang belum sebesar 23 (22\%). Rata-rata uang saku responden adalah $\mathrm{Rp}$ $800.000,00$.
Tabel 1. Distribusi Sampel Berdasarkan Jenis Kelamin

\begin{tabular}{cccc}
\hline No & Jenis Kelamin & $\mathbf{N}$ & $\mathbf{\%}$ \\
\hline 1 & Laki-laki & 15 & 14,15 \\
2 & Perempuan & 91 & 85,85 \\
\hline \multicolumn{7}{c}{ Total } & $\mathbf{1 0 6}$ & $\mathbf{1 0 0}$ \\
\hline Berdasarkan & tabel & 1. diatas dapat \\
diketahui sebagian & besar & responden adalah \\
perempuan sebesar $85,85 \%$.
\end{tabular}

Tabel 2. Distribusi Sampel Berdasarkan Tingkat Pengetahuan PHBS

\begin{tabular}{|c|c|c|c|}
\hline No & $\begin{array}{c}\text { Tk. Pengetahuan } \\
\text { PHBS }\end{array}$ & $\mathbf{N}$ & $\%$ \\
\hline 1 & Kurang & 19 & 17,1 \\
\hline 2 & Baik & 87 & 82,9 \\
\hline & Total & 106 & 100 \\
\hline
\end{tabular}

diketahui sebagian besar responden memiliki tingkat pengetahuan PHBS baik sebesar 82,9\%.

Tabel 3. Distribusi Sampel Berdasarkan Perilaku Germas

\begin{tabular}{|c|c|c|c|}
\hline No & Perilaku Germas & $\mathbf{N}$ & $\%$ \\
\hline 1 & Kurang & 38 & 35,8 \\
\hline \multirow[t]{2}{*}{2} & Baik & 68 & 64,2 \\
\hline & Total & 106 & 100 \\
\hline
\end{tabular}

Berdasarkan tabel 6. menunjukkan bahwa responden sebagian besar berperilaku germas baik $(64,2 \%)$.

Tabel 4. Pengaruh Tingkat Penegetahuan PHS dengan Perilaku Germas Mahasiswa Poltekkes Kemenkes Palangka Raya

\begin{tabular}{|c|c|c|c|c|c|c|c|c|}
\hline \multirow{3}{*}{ No } & \multirow{3}{*}{$\begin{array}{c}\text { Tk. } \\
\text { Pengeta } \\
\text { huan } \\
\text { PHBS }\end{array}$} & \multicolumn{4}{|c|}{ Perilaku Germas } & \multirow{2}{*}{\multicolumn{2}{|c|}{ Jumlah }} & \multirow{3}{*}{$\begin{array}{c}p- \\
\text { value }\end{array}$} \\
\hline & & \multicolumn{2}{|c|}{ Kurang } & \multicolumn{2}{|c|}{ Baik } & & & \\
\hline & & $\mathbf{N}$ & $\%$ & $\mathbf{N}$ & $\%$ & $\mathbf{N}$ & $\%$ & \\
\hline 1 & Kurang & 12 & 63,2 & 7 & 36,8 & 19 & 100 & \multirow{2}{*}{0,003} \\
\hline \multirow[t]{2}{*}{2} & Baik & 26 & 29,9 & 61 & 70,1 & 14 & 100 & \\
\hline & Jumlah & 38 & & 68 & & 106 & 100 & \\
\hline
\end{tabular}

Tabel 4 menunjukkan responden yang memiliki tingkat penegtahuan PHBS baik memiliki perilaku germas baik sebesar $70,1 \%$ daripada kurang $(63,2 \%)$ Selanjutnya 
berdasarkan hasil uji statistik Mann Whitney Test diketahui bahwa ada pengaruh yang bermakna antara tingkat pengetahuan PHBS yang dimiliki responden dengan perilaku germasnyak ( $p$-value $<0,05)$.

\section{HASIL}

Pelaksanaan upaya PHBS di sekolah secara langsung menggabungkan potensi orang tua, dosen, dan mahasiswa setempat. Dosen diarahkan untuk membantu pelaksanaan PHBS pada tatanan institusi pendidikan. Selain itu dosen dapat mendorong mahasiswa dalam melaksanakan PHBS. Menurut Green dosen mempunyai peran terhadap perilaku mahasiswa dalam memelihara kesehatannya. Dosen dapat berperan sebagai konselor, pemberi instruksi, motivator, manajer yang baik dalam pelaksanaan PHBS.

Berdasarkan data table 1 mengenai tingkat pengetahuan PHBS menunjukkan kategori baik sebesar $82,1 \%$ dan yang kurang adalah $17,9 \%$. Untuk meningkatkan tingkat pengetahuan mahasiswa tentang PHBS perlu dilakukan pembinaan dan promosi yang terus menerus, melalui pembiasaan dan penyuluhan pentingnya PHBS. Penyuluhan dapat dilakukan dengan cara penjelasan melalui poster, lembar balik maupun penempatan pesan-pesan PHBS ditempat-tempat yang strategis di kampus.

Perilaku Germas merupakan salah satu upaya untuk meningkatkan kesadaran, kemauan dan kemampuan masyarakat untuk berperilaku sehat dalam upaya meningkatkan kualitas hidup. Pembangunan kesehatan pada hakekatnya adalah upaya yang dilaksanakan oleh semua komponen Bangsa Indonesia yang bertujuan untuk meningkatkan kesadaran, kemampuan dan kemampuan hidup sehat bagi setiap orang agar terwujud derajat kesehatan masyarakat yang setinggi-tingginya.

Saat ini, Indonesia tengah mengalami perubahan pola penyakit yang sering disebut transisi epidemiologi yang ditandai dengan meningkatnya kematian dan kesakitan akibat penyakit tidak menular (PTM) seperti stroke, jantung, diabetes dan lain-lain.

Dampak meningkatnya kejadian PTM adalah meningkatnya pembiayaan pelayanan kesehatan yang harus ditanggung oleh masyarakat dan pemerintah; menurunnya produktivitas masyarakat; menurunnya daya saing negara yang pada akhirnya mempengaruhi kondisi sosial ekonomi masyarakat itu sendiri.

Melalui pembiasaan pada calon tenaga kesehatan diharapkan akan memberikan sumbangan bagi percepatan perubahan perilaku hidup sehat dengan menjadikan Germas adalah momentum yang baik untuk memberikan contoh nyata pada masyarakat.

\section{Kesimpulan}

1. Responden didominasi oleh perempuan, dengan tingkat pengetahuan PHBS baik lebih banyak $(82,9 \%)$ dan Perilaku Germas baik sebesar $64,2 \%$.

2. Ada pengaruh tingkat penegtahuan PHBS dengan perilaku Germas mahasiswa Poltekkes Kemenkes Palangka Raya, 
ditunjukkan dengan $p$ velue lebih kecil dari

0,05 yaitu 0,003 .

\section{DAFTAR PUSTAKA}

1. Permenkes RI Nomor : 2269/MENKES/PER/XI/2011 tentang Pedoman Pembinaan Perilaku Hidup Bersih dan Sehat.2011.

2. Notoatmodjo S. Promosi kesehatan dan Perilaku Kesehatan. Jakarta: Rineka Cipta, 2012.

3. Riset Kesehatan Dasar (RISKESDAS 2013). [Diakses 20 Januari 2016]. Available from: URL: http://www.riskesdas.litbang.depkes.go.id

4. Blum, Henrik L. (1983). Expanding Health Horizons: From a General Systems Concept of Health to a National Health Policy. Oakland, California: Third Party Publishing Company.

5. Dinas Kesehatan Provinsi Kalimantan Tengah. Profil Kesehatan Provinsi Kalimantan Tengah Tahun 2012 [internet]. Available fromwww.depkes.go.id diakses 22 Januari 2016.

6. Dinas Kesehatan Kota Palangka Raya. Profil Kesehatan Kota Palangka Raya Tahun 2014. Palangka Raya: Dinas Kesehatan Kota Palangka Raya, 2015.

7. Agus $\mathrm{R}$ dan Budiman. Kapita Selekta Kuesioner Pengetahuan dan Sikap Dalam Penelitian Kesehatan. Jakarta: Salemba Medika, 2013.

8. Depkes RI. Panduan Manajemen PHBS Menuju Kabupaten/Kota Sehat. Jakarta: Depkes RI, 2009.

9. Notoatmodjo S. Metodelogi Penelitian Kesehatan. Rineka Cipta: Jakarta, 2005. Promosi Kesehatan Teori dan Aplikasi. Rineka Cipta: Jakarta, 2005.

10. Green L.1980. Health Education Planning A Diagnostic Apporach. Baltimore. The John Hopkins University. Mayfield Publishing Co. 